\title{
Bird community in a forest patch isolated by the urban matrix at the Sinos River basin, Rio Grande do Sul State, Brazil, with comments on the possible local defaunation
}

\author{
Franz, I. *, Cappelatti, L. and Barros, MP. \\ Laboratório de Zoologia, Instituto de Ciências da Saúde, Centro Universitário Feevale, \\ Campus II, RS-239, 2755, CEP 93352-000, Novo Hamburgo, RS, Brazil \\ *e-mail: ismaelfranz@gmail.com \\ Received February 21, 2010 - Accepted April 29, 2010 - Distributed December 31, 2010
}

(With 3 figures)

\begin{abstract}
We compared the avifauna recorded in a recent survey in an urban park (Parque Municipal Henrique Luís Roessler, Parcão) and surroundings, Novo Hamburgo, RS, with past data, to evaluate the possible alterations in species composition over time. Of the 265 species compiled as original elements of that region, 114 were found at Parcão. Among forest species, $37 \%$ were considered locally extinct. The most affected guild was the large frugivores, with nine extinct species and one survivor (Trogon surrucura). Birds highly sensitive to disturbance as well as endemic species were the most extinguished. The possible causes for this loss are fragmentation, hunting and environmental changes. The diversity today is threatened, thus conservation measures are necessary in that region. The most important actions are: maintenance of ecological corridors, protection of natural remnant areas and the establishment of protected areas.
\end{abstract}

Keywords: avifauna, conservation, extinction, forest fragmentation.

\section{Comunidade de aves em um fragmento florestal isolado pela matriz urbana na bacia do Rio dos Sinos, Rio Grande do Sul, Brasil, com comentários sobre a possível defaunação local}

\begin{abstract}
Resumo
Comparamos a avifauna registrada em levantamento recente no Parque Municipal Henrique Luís Roessler e arredores, Novo Hamburgo, RS, com os registros do passado, com o objetivo de avaliar as possíveis alterações na composição de espécies ao longo do tempo. Das 265 espécies compiladas como elementos originais da região, 114 foram registradas no Parcão. Dentre as espécies florestais, $37 \%$ foram consideradas extintas localmente. A guilda mais afetada foi a dos frugívoros de grande porte, com nove espécies extintas e uma sobrevivente (Trogon surrucura). Aves endêmicas e com alta sensibilidade à perturbação nos hábitats se extinguiram mais. As prováveis causas dessas perdas são fragmentação, caça e descaracterização dos ambientes. A diversidade atual encontra-se ameaçada e, portanto, medidas de conservação se fazem necessárias na região. As mais importantes são: manutenção de corredores ecológicos, proteção dos remanescentes naturais e criação de unidades de conservação.
\end{abstract}

Palavras-chave: avifauna, conservação, extinção, fragmentação florestal.

\section{Introduction}

The advanced knowledge of bird biology compared to other animal groups, together with its own ecological characteristics, grants birds the important quality of excellent bio-indicators (Verner, 1981; Bibby, 1999). Thus, this group has been widely used in studies aiming to evaluate the effects that changes in natural areas have on biodiversity.

Several studies have shown that tropical forest fragmentation is a serious threat to biodiversity (revision in Turner, 1996). In the Neotropical region, some studies have led to direct and indirect evidence of population reduction and local extinction, due to forest habitat fragmentation, especially for the group of birds (Willis, 1974, 1979; Leck, 1979; Kattan et al., 1994; Stouffer and Bierregaard, 1995; Christiansen and Pitter, 1997; Renjifo, 1999; Robinson, 1999; Stratford and Stouffer, 1999).

The region of Sinos River basin is among the most populated areas in the state of Rio Grande do Sul (south Brazil) and has a history marked by European colonisation (through the colony of São Leopoldo), which occurred from 
the $19^{\text {th }}$ century until the mid 1940 's. The occupation of the lowlands and slopes led to the disfiguration of the majority of natural areas. Forests were substituted by plantations and later, by urban aggregations. Novo Hamburgo, for instance, one of the first built cities, has less than $8 \%$ of its original coverage (Fundação SOS Mata Atlântica, 2009). These modifications of natural environments caused an impoverishment of the local fauna.

The Sinos River basin has few studies focusing on its ornithological aspects, especially in the past decade. The work accomplished by ornithologist Walter Adolfo Voss during half of the 1970's, in the surroundings of São Leopoldo, is worthy of attention (Voss, 1976, 1977a, b, 1979a; Voss and Sander, 1979a, b).

This work presents a list of bird species in an isolated forest fragment in the city of Novo Hamburgo. We outlined a comparative analysis of its composition with the available data on how bird communities used to be at this region in the recent past, discussing the possible effects of human impacts on the local bird diversity.

\section{Material and Methods}

\subsection{Study area}

The study area is an urban park (29 $41^{\prime} \mathrm{S}$ and $\left.51^{\circ} 06^{\prime} \mathrm{W}\right)$ of 54 ha ( 40 ha are covered by forests) located in the city of Novo Hamburgo, Rio Grande do Sul State, South Brazil. The Parque Municipal Henrique Luís Roessler is popularly known as Parcão (and so-called hereafter). The region is included in the Lowland Semideciduous Forest formation (Teixeira et al., 1986), with an altitude ranging from 10 to $80 \mathrm{~m}$, characterised by a low canopy (less than $12 \mathrm{~m}$ high). Some characteristic tree species that can be cited are Myrsine coriacea, M. umbellata, Guarea macrophylla, Psidium cattleyanum, Ocotea pulchella, Casearia sylvestris and Cupania vernalis (Cappelatti and Schmitt, 2009). The area is considerably isolated, since it is completely surrounded by buildings and the nearest vegetation is distant ca. $1500 \mathrm{~m}$ (Figure 1). According to Maluf (2000), the regional climate is Subtropical, with a mean temperature of $19^{\circ} \mathrm{C}$.

\subsection{Survey methods}

Between 2005 and 2009, we accomplished sporadic expeditions to the park in order to develop a qualitative survey of the avifauna, which aimed to contribute to conservation measures for that area. For the sampling we made observations with the help of $7 \times 35$ binoculars, together with the recognition and recording of the vocalisations (with a digital recorder and a directional microphone), following the usual procedures in ornithology. The different succession stages of the forest (early to medium) were sampled in all seasons of the year. When relevant for discussion, we used other bird records for the city of Novo Hamburgo or nearby cities obtained by the first author during the last five years.

The scientific names follow the Brazilian Committee for Ornithological Records (CBRO, 2009). The species cited as endemic for the Atlantic forest were consulted in
Brooks et al. (1999) and we used the same guilds created by Willis (1979) for classifying the species. The birds were separated according to their sensitivity to habitat disturbance in three degrees (low, medium and high) based on Parker III et al. (1996).

\subsection{Temporal comparative analysis}

In order to list the bird species that occurred in the past decades at the region, we made a bibliographic survey from all the available studies. We considered as past on a short/medium scale the records from 1970 to early 1990. The main sources were the work of Belton (1994) and of Walter A. Voss (as mentioned before), who lived in Novo Hamburgo. Older records, as those obtained by Hermann von Ihering in nearby cities (especially at Igrejinha) in the $19^{\text {th }}$ century (Berlepsch and Ihering, 1885) and the ones based on the study of Emil Kaempfer in Novo Hamburgo, Sapiranga and Igrejinha (Naumburg, 1937, 1939) were considered as long-term and analysed secondarily. Based on these former and current records we discuss the probable alterations in the species composition and their possible causes.

Considering the particularities from each study and sampling time, which could make the comparisons difficult, we intended to use mainly the species that use forest habitats, from all successional stages. For instance, some species are exclusive of, or prefer, a specific altitude range. Since Parcão can be considered as a plain area, hardly reaching $90 \mathrm{~m}$ above sea level, any species present in the slopes and at a higher altitude would not normally occur there, for ecological reasons. Therefore, the absence of a species found in the past does not imply local extinction. The biological and ecological characteristics of each species were also considered and analysed, based mainly on Belton (1994).

\section{Results}

\subsection{Past ornithological records}

The compilation of former bird records near Novo Hamburgo resulted in 265 species, recorded between the end of the $19^{\text {th }}$ century and 1986 . Of those, $130(49 \%)$ inhabit forest environments and 33 are endemic to the Atlantic forest. Some of the species recorded by traveller naturalists are not present in the most complete texts and lists of the 1970 decade because they did not exist anymore by that time. That is the case of Asio stygius, mentioned for Novo Hamburgo in 1898 but without later records. Based on the maps from Belton (1994), we found that many species had (and most of them still have), in that area, their limit of distribution (mainly for the south). That region hosts the transition of the central depression with the northeast highland inferior slope, a fact that grants it the occurrence of distinct environmental characteristics. Two species show Novo Hamburgo as an exclusive record site for the state: Coturnicops notatus (a wetland species) and Arremon semitorquatus (a forest species).

The bird survey of the region of Novo Hamburgo mentioned earlier is the widest possible, including potential 

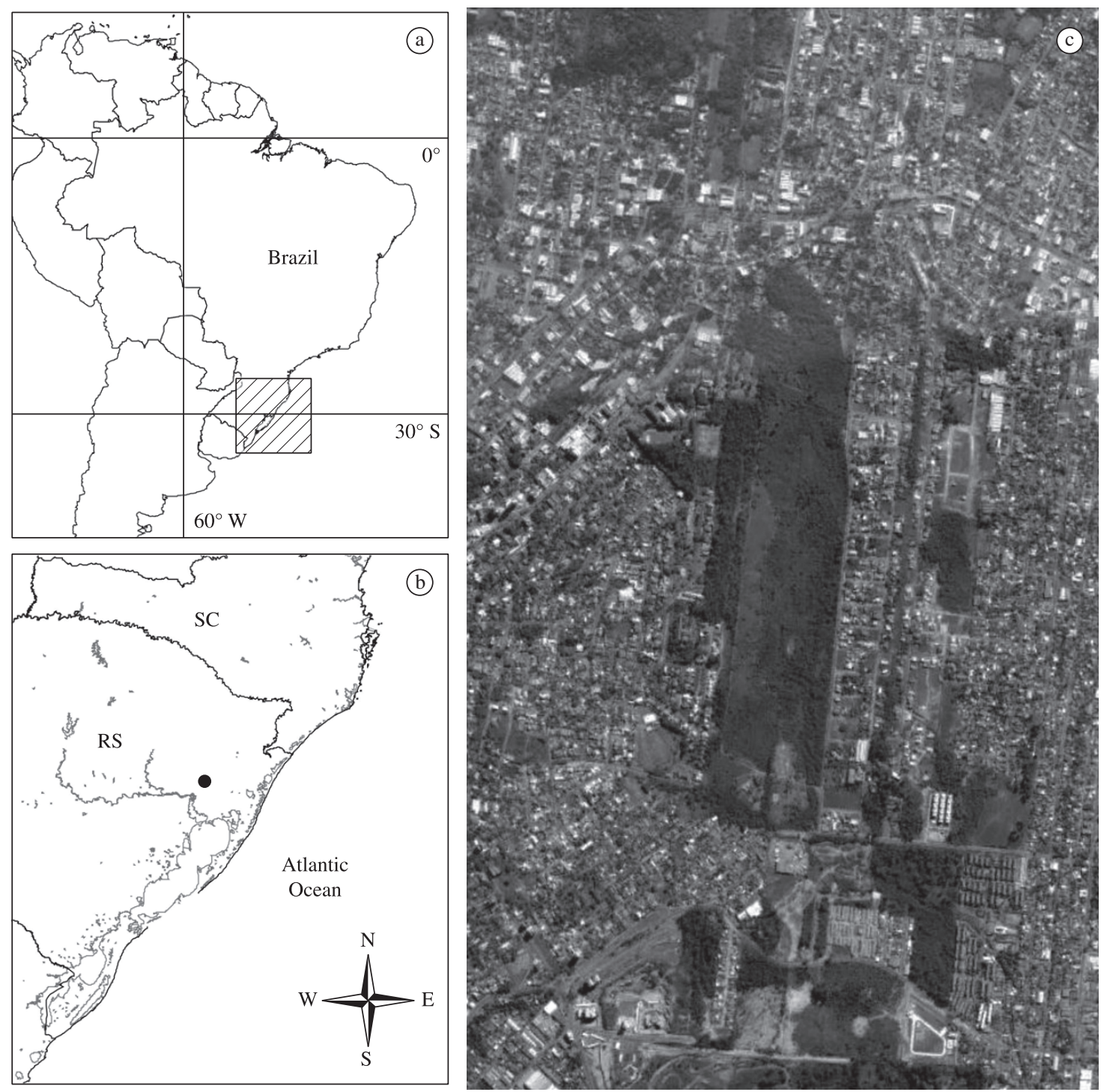

Figure 1. Location of the study area, Parque Municipal Henrique Luís Roessler, in the urban matrix of Novo Hamburgo (c), Rio Grande do Sul State (b), Brazil (a).

records from nearby cities (e.g. São Leopoldo) and species frequent in all habitats from the Sinos River basin. However, considering what we described regarding the absence of certain environments in Parcão, notably the open ones (the forest matrix is almost absolute), a few exclusions on the former list were necessary. Thus, among the forest species, we removed the ones that are exclusive of, or prefer, slopes or higher altitudes. These are: Picumnus nebulosus, Xenops rutilans, Heliobletus contaminatus, Leptopogon amaurocephalus, Mionectes rufiventris and Euphonia chalybea. Due to its dependence on fruiting bamboo species, Haplospiza unicolor was excluded as well. We did not consider Aramides cajanea as a former occurring species because of its preference for forests that are close to water or wetlands. Similarly, Coccyzus melacoryphus was excluded for apparently preferring forest patches located near wet areas. We did not consider nine species of nocturnal birds, because the little effort spent during night-time was not enough for comparisons. Amazona pretrei was not excluded, but we considered that this species would hardly have this region as part of its life area, although it nests in the region of the Central Depression. We eventually got a list of 112 species of forest birds (18 were excluded from the total 130) which occurred around the Parcão.

\subsection{Present survey and temporal comparisons}

In total, with a sampling effort of approximately 100 hours (21 days), 114 species of birds were recorded in Parcão. Of these, 71 (62\%) were considered primary forest birds and 18 are endemics of the Atlantic forest (Table 1). This number represents $18 \%$ of the birds in the state of Rio Grande do Sul (Bencke, 2001). The Appendix 
Table 1. Diurnal forest birds recorded in Parque Municipal Henrique Luís Roessler, Novo Hamburgo, Rio Grande do Sul state, Brazil, including the possibly extinct species, in guilds and categories of sensitivity, and indicating the endemics. Legend: AFE - Atlantic forest endemics.

\begin{tabular}{|c|c|c|c|}
\hline Species per guilds* & Possibly extinct & Sensitivity & Endemism \\
\hline \multicolumn{4}{|l|}{ Large frugivores } \\
\hline Ortalis guttata & $\mathrm{X}$ & Low & \\
\hline Pyrrhura frontalis & $\mathrm{X}$ & Medium & AFE \\
\hline Amazona pretrei & $\mathrm{X}$ & Medium & AFE \\
\hline Triclaria malachitacea & $\mathrm{X}$ & Medium & AFE \\
\hline Ramphastos dicolorus & $\mathrm{X}$ & Medium & AFE \\
\hline Trogon surrucura & & Medium & AFE \\
\hline Tityra cayana & $\mathrm{X}$ & Medium & \\
\hline Carpornis cucullata & $\mathrm{X}$ & High & AFE \\
\hline Procnias nudicollis & $\mathrm{X}$ & Medium & AFE \\
\hline Cyanocorax caeruleus & $\mathrm{X}$ & Medium & AFE \\
\hline \multicolumn{4}{|l|}{ Canopy omnivores } \\
\hline Camptostoma obsoletum & & Low & \\
\hline Vireo olivaceus & & Low & \\
\hline Pipraeidea melanonota & & Low & \\
\hline Euphonia chlorotica & & Low & \\
\hline Euphonia pectoralis & & Medium & AFE \\
\hline Euphonia cyanocephala & & Low & \\
\hline Euphonia violacea & $\mathrm{X}$ & Low & \\
\hline Dacnis cayana & $\mathrm{X}$ & Low & \\
\hline Tangara preciosa & $\mathrm{X}$ & Low & \\
\hline Hemithraupis guira & $\mathrm{X}$ & Low & \\
\hline Cacicus chrysopterus & $X$ & Medium & \\
\hline \multicolumn{4}{|l|}{ Understory omnivores } \\
\hline Chiroxiphia caudata & & Low & AFE \\
\hline Turdus subalaris & $\mathrm{X}$ & Low & AFE \\
\hline Turdus albicollis & & Medium & \\
\hline Habia rubica & $X$ & High & \\
\hline Trichothraupis melanops & $X$ & Medium & \\
\hline \multicolumn{4}{|l|}{ Edge omnivores or frugivores } \\
\hline Patagioenas picazuro & & Medium & \\
\hline Elaenia parvirostris & & Low & \\
\hline Elaenia flavogaster & & Low & \\
\hline Elaenia obscura & & Medium & \\
\hline Elaenia mesoleuca & & Low & \\
\hline Myiarchus swainsoni & & Low & \\
\hline Megarhynchus pitangua & & Low & \\
\hline Myiodynastes maculatus & & Low & \\
\hline Legatus leucophaius & $X$ & Low & \\
\hline Empidonomus varius & & Low & \\
\hline Turdus flavipes & $\mathrm{X}$ & Medium & \\
\hline Turdus rufiventris & & Low & \\
\hline Turdus leucomelas & & Low & \\
\hline Turdus amaurochalinus & & Low & \\
\hline Saltator similis & & Low & \\
\hline
\end{tabular}


Table 1. Continued...

\begin{tabular}{|c|c|c|c|}
\hline $\begin{array}{l}\text { Species per guilds* } \\
\end{array}$ & Possibly extinct & Sensitivity & Endemism \\
\hline Thraupis sayaca & & Low & \\
\hline Thraupis bonariensis & & Low & \\
\hline Tachyphonus coronatus & & Low & $\mathrm{AFE}$ \\
\hline Cyanoloxia brissonii & $\mathrm{X}$ & Medium & \\
\hline Cyanoloxia glaucocaerulea & $\mathrm{X}$ & Low & \\
\hline Stephanophorus diadematus & $\mathrm{X}$ & Low & \\
\hline Tersina viridis & $\mathrm{X}$ & Low & \\
\hline Coryphospingus cucullatus & & Low & \\
\hline Icterus cayanensis & & Medium & \\
\hline \multicolumn{4}{|l|}{ Ground frugivores } \\
\hline Crypturellus obsoletus & & Low & \\
\hline Crypturellus tataupa & $\mathrm{X}$ & Low & \\
\hline Leptotila verreauxi & & Low & \\
\hline Leptotila rufaxilla & & Medium & \\
\hline Geotrygon montana & $\mathrm{X}$ & Medium & \\
\hline \multicolumn{4}{|l|}{ Carnivores } \\
\hline Rupornis magnirostris & & Low & \\
\hline Harpagus diodon & $\mathrm{X}$ & Medium & \\
\hline Accipiter striatus & $\mathrm{X}$ & Low & \\
\hline Micrastur semitorquatus & $\mathrm{X}$ & Medium & \\
\hline \multicolumn{4}{|l|}{ Trunk and twig insectivores } \\
\hline Picumnus temminckii & & Medium & AFE \\
\hline Veniliornis spilogaster & & Medium & AFE \\
\hline Piculus aurulentus & & Medium & AFE \\
\hline Dryocopus galeatus & $\mathrm{X}$ & High & AFE \\
\hline Dryocopus lineatus & $\mathrm{X}$ & Medium & \\
\hline Celeus flavescens & $X$ & Medium & \\
\hline Colaptes melanochloros & & Low & \\
\hline Sittasomus griseicapillus & & Medium & \\
\hline Dendrocolaptes platyrostris & $\mathrm{X}$ & Medium & \\
\hline Lepidocolaptes falcinellus & & High & AFE \\
\hline \multicolumn{4}{|l|}{ Ground insectivores } \\
\hline Aramides saracura & & Medium & $\mathrm{AFE}$ \\
\hline Chamaeza campanisona & $\mathrm{X}$ & High & \\
\hline Sclerurus scansor & & High & AFE \\
\hline \multicolumn{4}{|l|}{ Understory insectivores } \\
\hline Piaya cayana & & Low & \\
\hline Batara cinerea & & Medium & \\
\hline Mackenziaena leachii & & Medium & AFE \\
\hline Thamnophilus caerulescens & & Low & \\
\hline Dysithamnus mentalis & & Medium & \\
\hline Synallaxis cinerascens & & Medium & \\
\hline Synallaxis ruficapilla & & Medium & AFE \\
\hline Cranioleuca obsoleta & & Medium & AFE \\
\hline Syndactila rufosuperciliata & & Medium & \\
\hline Lochmias nematura & $\mathrm{X}$ & Medium & \\
\hline Conopophaga lineata & & Medium & AFE \\
\hline Pachyramphus viridis & $\mathrm{X}$ & Medium & \\
\hline
\end{tabular}


Table 1. Continued...

\begin{tabular}{|c|c|c|c|}
\hline Species per guilds* & Possibly extinct & Sensitivity & Endemism \\
\hline Poecilotriccus plumbeiceps & & Medium & \\
\hline Platyrinchus mystaceus & & Medium & \\
\hline Tolmomyias sulphurescens & & Medium & \\
\hline Pyrrhocoma ruficeps & $\mathrm{X}$ & Medium & AFE \\
\hline Basileuterus culicivorus & & Medium & \\
\hline Basileuterus leucoblepharus & & Medium & AFE \\
\hline Arremon semitorquatus & $\mathrm{X}$ & Medium & \\
\hline \multicolumn{4}{|l|}{ Canopy insectivores } \\
\hline Phylloscartes ventralis & & Medium & \\
\hline Pachyramphus polychopterus & & Low & \\
\hline Cyclarhis gujanensis & & Low & \\
\hline Parula pitiayumi & & Medium & \\
\hline \multicolumn{4}{|l|}{ Edge insectivores } \\
\hline Tapera naevia & & Low & \\
\hline Thamnophilus ruficapillus & & Low & \\
\hline Synallaxis spixi & & Low & \\
\hline Knipolegus cyanirostris & $\mathrm{X}$ & Low & \\
\hline Serpophaga subcristata & & Low & \\
\hline Troglodytes musculus & & Low & \\
\hline Geothlypis aequinoctialis & & Low & \\
\hline \multicolumn{4}{|l|}{ Aerial insectivores } \\
\hline Ictinia plumbea & & Medium & \\
\hline \multicolumn{4}{|l|}{ Nectar and insect eaters } \\
\hline Florisuga fusca & & Medium & AFE \\
\hline Anthracothorax nigricollis & $\mathrm{X}$ & Low & \\
\hline Stephanoxis lalandi & & Medium & AFE \\
\hline Chlorostilbon aureoventris & & Low & \\
\hline Leucochloris albicollis & & Low & AFE \\
\hline Thalurania glaucopis & $\mathrm{X}$ & Medium & AFE \\
\hline Amazilia versicolor & $\mathrm{X}$ & Low & \\
\hline Hylocharis chrysura & & Low & \\
\hline Coereba flaveola & & Low & \\
\hline
\end{tabular}

includes the non-forest species recorded $(n=43)$. Of the 71 analysed species, 18 (25\%) belong to the guild of edge omnivores or frugivores, $15(21 \%)$ of understory insectivores, six (8\%) of canopy omnivores, six of trunk and twig insectivores, six of edge insectivores, six of nectar and insect eaters, four $(5.5 \%)$ of canopy insectivores, three $(4 \%)$ of the ground frugivores, two $(3 \%)$ of understory omnivores, two of ground insectivores, one (1.4\%) of large frugivores, one of carnivores and one of aerial insectivores. Of the 125 forest species considered as occurring in the past, 41 (33\%) were not recorded in this study, thus considered as probably extinct. Myiophobus fasciatus and Lathrotriccus euleri, not recorded, may have been missed in the sampling and were not included as extinct. The largest number of extinct species belong to the guild of large frugivores $(n=9,22 \%)$, followed by the edge omnivores or frugivores $(n=6,15 \%)$, canopy omnivores $(\mathrm{n}=5,12 \%)$ and others (Figure 2).

On the sensitivity to environmental disturbance, $39(55 \%)$ species belong to the category "low", 30 (42\%) to "medium" and two (3\%) to "high". Species considered as possibly extinct had majority in the two categories of higher sensitivity (Figure 3).

\section{Discussion}

At first, the species richness found in Parcão $(\mathrm{n}=114)$ may be considered low. Nonetheless, we must bring into account its small size ( $\sim 50$ ha), the advanced level of human impact and its isolation, all considered to impoverish avifauna (Dorp and Opdam, 1987; Marsden et al., 2001). Anjos and Boçon (1999) sampled small fragments (0.5 to 40 ha) and compared them to a control area in Paraná. The 


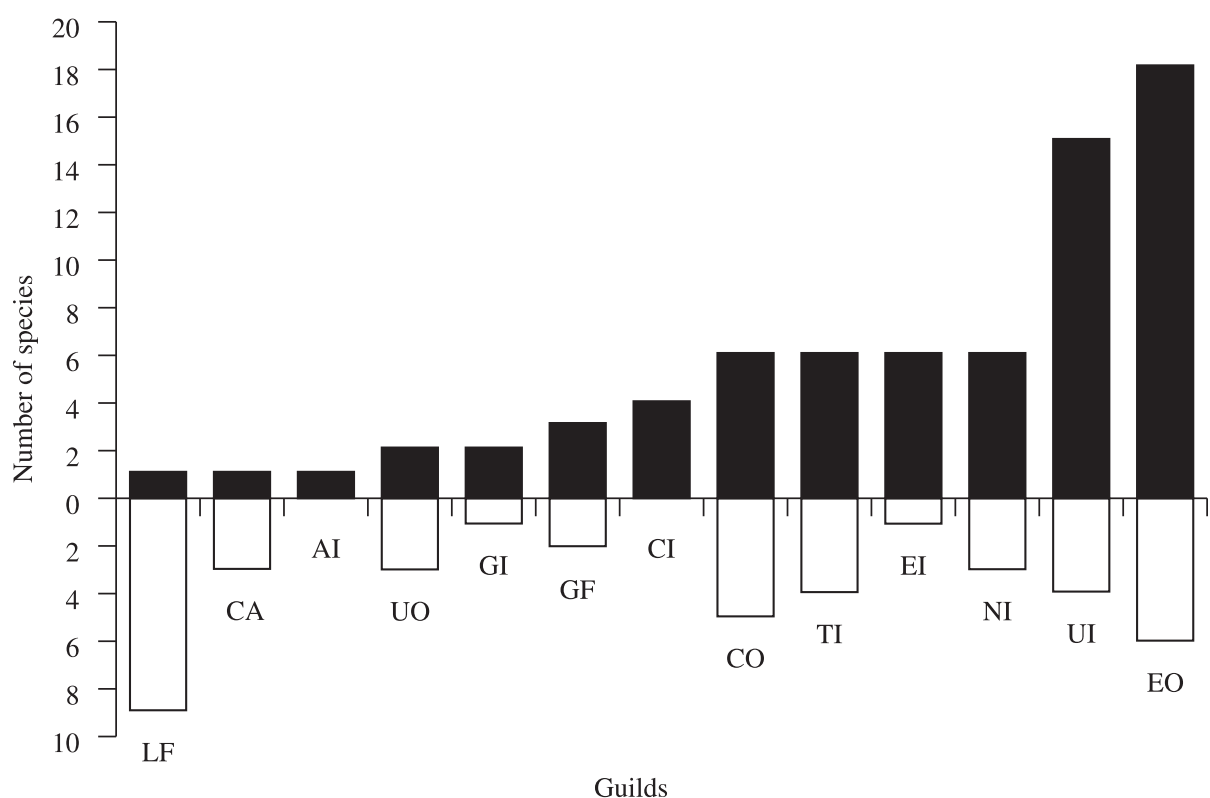

Figure 2. Number of surviving (black bars) and extinct (white bars) forest bird species of Parque Municipal Henrique Luís Roessler, Novo Hamburgo, Rio Grande do Sul State, Brazil, distributed in guilds. LF: large frugivores, CA: carnivores, AI: aerial insectivores, UO: understory omnivores, GI: ground insectivores, GF: ground frugivores, CI: canopy insectivores, CO: canopy omnivores, TI: trunk and twig insectivores, EI: edge insectivores, NI: nectar and insect eaters, UI: understory insectivores, EO: edge omnivores or frugivores.

authors recorded 93 species at the patch of 40 ha and found a clear correlation between fragment size and bird richness. Pozza and Pires (2003) recorded 145 and 173 species in isolated forest fragments of 74 and 100 ha, respectively, in the interior of São Paulo. D’Angelo-Neto et al. (1998) conducted a bird survey in four small patches of forest ( $<8 \mathrm{ha}$ ) and found a total of 107 species. Lopes and Anjos (2006) recorded 109 species in 20 ha of forest at the campus of Universidade Estadual de Londrina, Paraná. Krügel and Anjos (2000) found 110 species in a park of 47 ha, and 560 m from downtown Maringá, Paraná. In an area apparently similar to Parcão, an isolated park of 80 ha at the centre of Blumenau, Santa Catarina state, Zimmermann (1999) recorded 112 species. Compared to this data, the area of Parcão presents a similar richness for regional patterns, fulfilling its role in contributing to the maintenance of the local biodiversity. In a typically urban and artificial environment, where diversity is extremely low, islands of nature can have an increase in its effectiveness for conservation, acting as samples of the persisting local richness.

According to Cappelatti and Schmitt (2009), most of Parcão is at an early stage of succession, with more than $60 \%$ of pioneer tree species. Also, Marchioretto et al. (2001) observed a slow regeneration in the park, due to the isolation of the area by the city. For birds, the quality of forest environments may also define if some species will persist in a fragment, and that fact is worth considering as much as fragment size and isolation (Stouffer and Bierregaard, 1995; Marsden et al., 2001). To exemplify

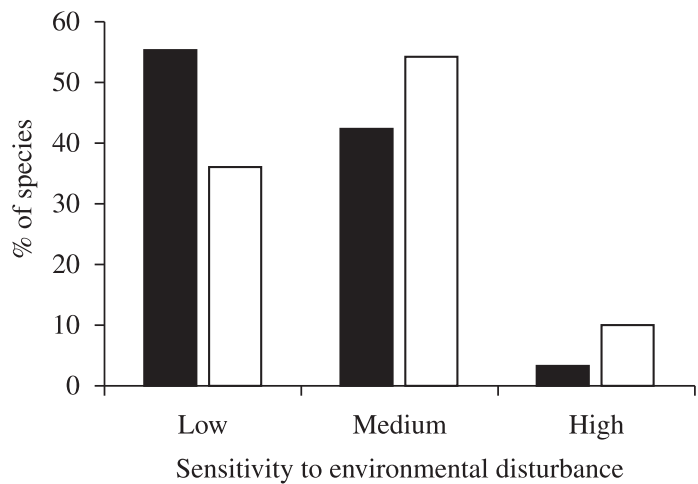

Figure 3. Percentage of surviving (black bars) and extinct (white bars) forest bird species of Parque Municipal Henrique Luís Roessler, Novo Hamburgo, Rio Grande do Sul State, Brazil, in categories of sensitivity to environmental disturbance.

this statement, we can mention Habia rubica, an extinct species at Parcão and nearby areas, which is easily recognised by its active behaviour, formation of mixedflocks and frequent vocalisation. This species was found in smaller forest fragments in the Sinos River basin, including an area of 3 ha in the nearby city of Estância Velha. H. rubica uses a specific microhabitat, characterised by a dense understory and low light (Fávaro and Anjos, 2005). Therefore, this species does not occur in forests with scarce vegetation and little shadow, such as young and degraded forests. Also, Cappelatti and Schmitt (2009) 
highlighted the importance of seed dispersal by birds for the forest regeneration through tree succession in Parcão (the tree survey demonstrated a high prevalence of animaldispersed trees - 82\%). Defaunation (extinction of animal species from an ecosystem), still not satisfactorily studied, has a serious role in the loss of ecological processes, by affecting animal-plant relationships, also resulting in biodiversity reduction (Jordano et al., 2006).

On July $31^{\text {st }}$, 1928, traveller naturalist Emil Kaempfer had been in the neighbourhood of Hamburgo Velho where colonisation began and where Parcão is situated. At the time, he described the area as "a hilly region with flat valleys and in the depressions small streams flow across country. Large stretches of original forests are still left" (Naumburg, 1935). Today, not even the "hilly" aspect of it can be clearly identified, such is the effect of human transformations happening during the following decades, especially from 1940 on, when German immigration intensified.

Thereby it is documented that deforestation has been occurring in the surroundings of Parcão for less than 80 years. Unlike other regions from the same river basin which had an increase in forest coverage since the 1960 decade, with families migrating to other cities, Novo Hamburgo always maintained its characteristic as an urban and industrial city. As a whole, the inferior course of Sinos River is characterised by a large industrial development and a high demographic density, which causes a series of environmental problems (Rolon et al., 2003).

Sodhi et al. (2005), analysing the avifaunal turnover in an isolated fragment of 4 ha in Singapura, concluded that after 100 years, $49 \%$ of the birds would be extinct. Castaño-Villa and Patiño-Zabala (2008) noted the disappearing of 78, 66 and $63 \%$ of species in fragments of 41, 129 and 136 ha, respectively, in Colombia. In a recent study at the floodplain of Paraná River, Mendonça et al. (2009) showed that 21\% of the birds may have been locally extinct. Fontana (2005) indicates that 27 (10.5\%) of the 257 bird species recorded for Porto Alegre, Rio Grande do Sul state, have become extinct during the last century or will be in the near future. From the 112 forest species compiled for Parcão and adjacent areas, $41(37 \%)$ are considered locally extinct.

One of the most common effects of habitat fragmentation is the alteration of animal diversity through extinction and colonisation (Jordano et al., 2006). Among the bird guilds most affected by habitat loss are those of large frugivores and of understory and ground insectivores (Aleixo, 1999; Pizo, 2001). Large fruit consumers need availability of resources throughout the year and, during food shortage at smaller fragments that do not carry enough biomass, they are bound to move in the search of new food sources (Willis, 1979). For understory insectivores, fragment size does not appear to be the main coefficient involved in decline, but the species' capacity of dispersing in deforested areas (Sekercioglu et al., 2002). Trunk and twig insectivores occur in smaller diversity as the fragment size decreases (Willis, 1979; Soares and Anjos, 1999). In the present study the guild of edge omnivores or frugivores presented the largest amount of species today $(\mathrm{n}=18$, $25 \%$ ) in Parcão and may indicate the strong edge effect that this fragment suffers. It has come to our attention that, of the 10 potential species belonging to the guild of large frugivores, only one (Trogon surrucura) was found. The other nine were considered extinct. With the increase of deforestation and other threats throughout the $20^{\text {th }}$ century, the local populations of these species were, little by little, losing their habitat and declining until their survival was impossible. Procnias nudicollis is virtually not found anymore in the Sinos River basin. Triclaria malachitacea, Carpornis cucullata, Cyanocorax caeruleus and Tityra cayana occur in higher, larger and more conserved forests at the escarpment base, which begins around $1.5 \mathrm{~km}$ north of Parcão. The first one is apparently scarcer and may be declining faster. Eleven species constituted the canopy omnivores guild, five of which are extinct. The loss of half of the species belonging to this group may be related to the absence of extended areas with older and taller forests. In a similar way, trunk and twig insectivores had 10 species, four of them considered extinct. The results confirm what literature indicates, that specialist species extinguish more than those with higher ecological plasticity.

Proportionally, more species sensitive to habitat disturbance became extinct when compared to the "survivors" of today (Figure 3), which are the least sensitive species. Four of the six most sensitive species are extinct and four are endemic from Atlantic forest. The two species that are still present (Lepidocolaptes falcinellus and Sclerurus scansor), both endemic, belong to the sensitive groups of trunk climbers and ground insectivores, respectively. Thus, these species are in danger of becoming extinct at Parcão in the next few years. Another species that may be endangered in terms of local extinction is Trogon surrucura (medium sensitivity, endemic, large frugivore) alongside besides Turdus albicollis, Piculus aurulentus and Batara cinerea. Some species we considered extinct were also considered extinct by Fontana (2005) in Porto Alegre. This may indicate that certain species are more susceptible to decline in the great region of the Lake Guaíba (where Sinos River is situated). Thalurania glaucopis, Dendrocolaptes platyrostris, Pachyramphus viridis, Carpornis cucullata, Turdus flavipes, Cyanoloxia glaucocaerulea, C. brissonii, Euphonia violacea and Cyanocorax caeruleus were considered extinct in both studies. Brooks et al. (1999) predicted that $30-50 \%$ of endemic birds from the Atlantic forest may be extinguished in a mid-term future due to deforestation. The work conducted by Mendonça et al. (2009) in the state of Paraná showed that endemism, proximity to the geographic limit of distribution, low tolerance to human-altered environments and habitat specificity are characteristics associated to a potential loss of bird species. Similarly, Ribon et al. (2003) concluded that endemic species and those with high or medium sensitivity were extinguished or found themselves threatened proportionally more than those not endemic or with low sensitivity. More studies are necessary and it is important to consider the difficulty in comparing areas from different regions where 
birds may respond differently to alteration. To Anjos (2006), when the goal is to elaborate conservation measures, it is important to consider the differences in the sensitivity between birds at their centre of distribution and those near their limit of occurrence.

A few common species in Novo Hamburgo today may be considered cases of recent colonisation and/or increase of the local population. Turdus leucomelas has been expanding its distribution towards the south of the state (Bencke and Grillo, 1995). Today it is a frequent species in forest fragments, Eucalyptus plantations and even backyards. Estrilda astrild, introduced from Africa, was first seen in Novo Hamburgo in the 1970's (Voss, 1979b) and today is abundant in the Sinos River basin, usually associated with empty lands with grass. Myiopsitta monachus, according to our observations, appeared in Novo Hamburgo about seven years ago. It is seen nesting in tall Eucalyptus trees in rural areas or in the city, where it also uses the exotic pine Araucaria araucana. Florisuga fusca is expanding its distribution (Costa, RGA. and Costa, RCV., 2003) and is found in lowland forests as well as in the slopes of Sinos River basin. Caprimulgus longirostris, even though not seen in the surroundings of Parcão, is frequently heard downtown and at the periphery of the city. As seen by earlier authors, forest fragmentation today is one of the main causes of species loss. Adding to that, colonisation of natural areas by people brings several other activities which cause defaunation, like hunting, for example. Among the species considered extinct at the surroundings of Parcão, some were clearly extinct by reasons other than fragmentation. Ortalis guttata is a game species, very appreciated for its meat. Cyanoloxia spp. and Stephanophorus diadematus are not considered to be sensitive or to need perfect conditions to survive. On the other hand, they are widely hunted for captivity. The extinction of certain species in that region may have resulted from several causes associated to human occupation. Even parks and reserves, which should protect the residual fauna, sometimes do not offer protection for their survival (Jordano et al., 2006).

Two main results were here presented: 1) many bird species were extinguished in the region where Parcão is situated during the past decades, due to continuous habitat loss and change. Nonetheless; 2) the bird community that persisted showed important components: endemic, sensitive and endangered species. Based on that, we conclude that the area is under a strong threat and urgently requires conservation measures. The recovery of the vegetation is pointed out by Cappelatti and Schmitt (2009) as one of the most urgent actions, and it can only happen in an environment where interactions between fauna and flora occur naturally. The region of Sinos River basin needs public policies which will effectively guarantee the maintenance and natural succession of environments. In areas with a forest matrix such as that of Novo Hamburgo, the creation of ecological corridors, together with the conservation of larger remnant forest, as long as this is done based on appropriate studies, may be an important measure towards nature conservation. Finally, we stress that the participation of cities in the creation of protected areas and in the better management of the few areas that already exist would be an appreciated action.

Acknowledgements - We thank Dr. Jairo L. Schmitt for the supervision on the projects developed in Parcão. We are grateful to the Centro Universitário Feevale for the logistic support; to the staff and administration of Parcão for their effort in helping; and to the people who appreciate urban parks, using them in a sustainable way.

\section{References}

ALEIXO, A., 1999. Effects of selective logging on a bird community in the brazilian Atlantic forest. The Condor, vol. 101, p. $537-548$.

ANJOS, L. and BOÇON, R., 1999. Bird communities in natural forest patches in southern Brazil. The Wilson Bulletin, vol. 111, no. 3, p. 397-414.

ANJOS, L., 2006. Bird species sensitivity in a fragmented landscape of the Atlantic forest in southern Brazil. Biotropica, vol. 38 , no. 2, p. 229-234.

BELTON, W., 1994. Aves do Rio Grande do Sul: distribuição e biologia. São Leopoldo: Ed. Unisinos, 584 p.

BENCKE, GA. and GRILLO, H., 1995. Range expansion of the pale-breasted thrush Turdus leucomelas (Aves, Turdidae) in Rio Grande do Sul, Brazil. Iheringia - Série Zoologia, vol. 79, p. $175-176$.

BENCKE, GA., 2001. Lista de referência das aves do Rio Grande do Sul. Porto Alegre: Fundação Zoobotânica do Rio Grande do Sul, $102 \mathrm{p}$.

BERLEPSCH, H. von and IHERING, H. von, 1885. Die vögel der umgegend von Taquara do Mundo Novo, Prov. Rio Grande do Sul. Ornis - Zeitschrift für die gesammte Ornithologie, p. 1-88.

BIBBY, CJ., 1999. Making the most of birds as environmental indicators. Ostrich, vol. 70 , p. 81-88.

BROOKS, T., TOBIAS, J. and BALMFORD, A., 1999. Deforestation and bird extinctions in the Atlantic forest. Animal Conservation, vol. 2, p. 211-222.

CAPPELATTI, L. and SCHMITT, JL., 2009. Caracterização da flora arbórea de um fragmento urbano de floresta estacional semidecidual no Rio Grande do Sul, Brasil. Pesquisas, Botânica, vol. 60, p. 341-354.

CASTAÑO-VILLA, GJ. and PATIÑO-ZABALA, JC., 2008. Extinciones locales de aves en fragmentos de bosque en la región de Santa Elena, Andes Centrales, Colombia. Hornero, vol. 23, no. 1, p. 23-34

CHRISTIANSEN, MB. and PITTER, E., 1997. Species loss in a forest bird community near Lagoa Santa in southeastern Brazil. Biological Conservation, vol. 80, p. 23-32.

Comitê Brasileiro de Registros Ornitológicos - CBRO, 2009. Listas das aves do Brasil. Versão 9/8/2009. Available from: $<$ http://www.cbro.org.br>. Access in: $12 \mathrm{dez} .2009$.

COSTA, RGA. and COSTA, RCV., 2003. Expansão da distribuição geográfica do beija-flor-preto-de-rabo-branco, Melanotrochilus fuscus no Rio Grande do Sul. Atualidades Ornitológicas, vol. 116. 
D’ANGELO-NETO, S., VENTURIN, N., OLIVEIRA-FILHO, AT. and COSTA, FAF., 1998. Avifauna de quatro fisionomias florestais de pequeno tamanho (5-8 ha) no campus da UFLA. Revista Brasileira de Biologia = Brazilian Journal of Biology, vol. 58 , no. 3 , p. $463-472$

DORP, D. van. and OPDAM, PFM., 1987. Effects of patch size, isolation and regional abundance on forest bird communities. Landscape Ecology, vol. 1, no. 1, p. 59-73.

FÁVARO, FL. and ANJOS, L., 2005. Microhabitat de Habia rubica (Vieillot) e Trichothraupis melanops (Vieillot) (Aves, Emberizidae, Thraupinae), em uma floresta atlântica do sul do Brasil. Revista Brasileira de Zoologia, vol. 22, no. 1, p. 213-217.

FONTANA, CS., 2005. A ornitofauna em Porto Alegre no século XX: status de ocorrência e conservação. Comunicações do Museu de Ciências e Tecnologia da PUCRS, série Zoologia, vol. 18, no. 2, p. 161-206.

Fundação S.O.S Mata Atlântica, 2009. Atlas dos remanescentes florestais da Mata Atlântica. Período 2005-2008. São Paulo: Fundação S.O.S Mata Atlântica. Relatório Parcial.

JORDANO, P., GALETTI, M., PIZO, MA. and SILVA, WR. Ligando frugivoria e dispersão de sementes à biologia da conservação. In ROCHA, CFD., BERGALLO, HG., ALVES, MAS. and SLUYS, MV. Biologia da conservação: essências. São Paulo: Rima Ed., 2006, p. 411-436.

KATTAN, GH., ALVAREZ-LÓPEZ, H. and GIRALDO, M., 1994. Forest fragmentation and bird extinction: San Antonio eighty years later. Conservation Biology, vol. 8, p. 138-146.

KRÜGEL, MM. and ANJOS, L., 2000. Bird communities in forest remnants in the city of Maringá, Paraná state, southern Brazil. Ornitologia Neotropical, vol. 11, p. 315-330.

LECK, CF., 1979. Avian extinctions in an isolated tropical wetforest preserve, Ecuador. The Auk, vol. 96, p. 343-352.

LOPES, EV. and ANJOS, L., 2006. A composição da avifauna do campus da Universidade Estadual de Londrina, norte do Paraná, Brasil. Revista Brasileira de Zoologia, vol. 23, no. 1, p. $145-156$.

MALUF, JRT., 2000. Nova classificação climática do estado do Rio Grande do Sul. Revista Brasileira de Agrometeorologia, vol. 8, no. 1, p. 141-150.

MARCHIORETTO, MS., MAUHS, J., ROSA, AO. and PORT, D., 2001. Estádio sucessional de um fragmento de mata nativa em ambiente urbano. Pesquisas, Botânica, vol. 51, p. 129-135.

MARSDEN, SJ., WHIFFIN, M. and GALETTI, M., 2001. Bird diversity and abundance in forest fragments and Eucalyptus plantations around an Atlantic forest reserve, Brazil. Biodiversity and Conservation, vol. 10, p. 737-751.

MENDONÇA, LB., LOPES, EV. and ANJOS, L., 2009. On the possible extinction of bird species in the Upper Paraná River floodplain, Brazil. Brazilian Journal of Biology, vol. 69, suppl. 2, p. 747-755.

NAUMBURG, EMB., 1935. Gazetteer and maps showing stations visited by Emil Kaempfer in eastern Brazil and Paraguay. Bulletin of The American Museum of Natural History, vol. 68, p. 449-469.

-, 1937. Studies of birds from eastern Brazil and Paraguay, based on a collection made by Emil Kaempfer. Conopophagidae,
Rhinocryptidae, Formicariidae (part.). Bulletin of The American Museum of Natural History, vol. 74, p. 139-205.

-, 1939. Studies of birds from eastern Brazil and Paraguay, based on a collection made by Emil Kaempfer. Formicariidae. Bulletin of The American Museum of Natural History, vol. 76, p. 231-276.

PARKER III, TA., STOTZ, DF. and FITZPATRICK, JW. Ecological and distributional databases. In STOTZ, DF., FITZPATRICK, JW., PARKER III, TA. and MOSKOVITS, DK. Neotropical birds: ecology and conservation. Chicago and London: The University of Chicago Press, 1996, p. 113-436.

PIZO, MA. A conservação das aves frugívoras. In ALBUQUERQUE, JLB., CÂNDIDO-JR., JF., STRAUBE, FC. and ROOS, AL. Ornitologia e conservação: da ciência às estratégias. Tubarão. Editora Unisul, 2001, p. 49-59.

POZZA, DD. and PIRES, JSR., 2003. Bird communities in two fragments of semideciduous forest in rural São Paulo state. Brazilian Journal of Biology, vol. 63, no. 2, p. 307-319.

RENJIFO, LM., 1999. Composition changes in a subandean avifauna after long-term forest fragmentation. Conservation Biology, vol. 13, no. 5, p. 1124-1139.

RIBON, R., SIMON, JE. and MATTOS, GT., 2003. Bird extinctions in Atlantic forest fragments of the Viçosa Region, southeastern Brazil. Conservation Biology, vol. 17, no. 6, p. 1827-1839.

ROBINSON, W., 1999. Long-term changes in the avifauna of Barro Colorado Island, Panama, a tropical forest isolate. Conservation Biology, vol. 13, no. 1, p. 85-97.

ROLON, AS., OLIVA, TD. and MALTCHIK, L. Bacia do Rio dos Sinos. In MALTCHIK, L. Biodiversidade e conservação de áreas úmidas da bacia do Rio dos Sinos. São Leopoldo: Ed. Unisinos, 2003, p. 27-30.

SEKERCIOGLU, CH., EHRLICH, PR., DAILY, GC., AYGEN, D., GOEHRING, D. and SANDÍ, RF., 2002. Disappearance of insectivorous birds from tropical Forest fragments. Proceedings of the National Academy of Sciences, vol. 99, no. 1, p. 263-267.

SOARES, ES. and ANJOS, L., 1999. Efeito da fragmentação florestal sobre aves escaladoras de tronco e galho na região de Londrina, norte do estado do Paraná, Brasil. Ornitologia Neotropical, vol. 10, p. 61-68.

SODHI, NS., LEE, TM., KOH, LP. and DUNN, RR., 2005. A century of avifaunal turnover in a small tropical rainforest fragment. Animal Conservation, vol. 8, p. 217-222.

STOUFFER, PC. and BIERREGAARD, RO., 1995. Use of Amazonian forest fragments by understory insectivorous birds. Ecology, vol. 76, no. 8, p. 2429-2445.

STRATFORD, JA. and STOUFFER, P., 1999. Local extinctions of terrestrial insectivorous birds in a fragmented landscape near Manaus, Brazil. Conservation Biology, vol. 13, no. 6, p. 1416-1423.

TEIXEIRA, MB., COURA-NETO, AB., PASTORE, U. and RANGEL-FILHO, ALR., 1986. Vegetação. In Instituto Brasileiro de Geografia e Estatística - IBGE. Levantamento de recursos naturais. Rio de Janeiro: IBGE, vol. 33, p. 541-620.

TURNER, IM., 1996. Species loss in fragments of tropical rainforest: a review of the evidence. Journal of Applied Ecology, vol. 33, p. 200-209. 
VERNER, J., 1981. Measuring responses of avian communities to habitat manipulation. Studies in Avian Biology, vol. 6, p. 543-547.

VOSS, WA. and SANDER, M., 1979a. Aves de São Leopoldo. III - Aves observadas no Centro de Recreação do Trabalhador. Estudos Leopoldenses, vol. 50, p. 71-77.

-, 1979b. Aves de São Leopoldo. IV - Aves observadas no novo campus da Universidade do Vale do Rio dos Sinos - UNISINOS. Estudos Leopoldenses, vol. 50, p. 79-83.

VOSS, WA., 1976. Aves observadas nas cidades de Novo Hamburgo e São Leopoldo, RS. Estudos Leopoldenses, vol. 36, p. 43-53.

-, 1977a. Aves de São Leopoldo. I - Aves observadas no Bairro Recreio. Estudos Leopoldenses, vol. 41, p. 36-39.

-, 1977b. Aves de São Leopoldo. II - Aves observadas no banhado da Olaria Linck. Estudos Leopoldenses, vol. 41, p. 41-46.
-, 1979a. Aves observadas na área central da cidade de São Leopoldo, RS. Pesquisas, vol. 31, p. 9-24.

-, 1979b. Comunicação sobre a ocorrência do bico-de-lacre, Estrilda astrild (Linne, 1758), na cidade de Novo Hamburgo - RS (Estrildidae - Aves). Pesquisas, Zoologia, vol. 31, p. 25-28.

WILLIS, EO., 1974. Populations and local extinctions of birds on Barro Colorado Island, Panama. Ecological Monographs, vol. 44, p. 153-169.

-, 1979. The composition of avian communities in remanescent woodlots in southern Brazil. Papéis Avulsos de Zoologia, vol. 33 , no. 1, p. 1-25.

ZIMMERMANN, CE., 1999. Avifauna de um fragmento de Floresta Atlântica em Blumenau, Santa Catarina. Revista de Estudos Ambientais, vol. 1, no. 3, p. 101-112. 
Appendix. Birds (mostly non-forest species) of Parque Municipal Henrique Luís Roessler, Novo Hamburgo, Rio Grande do Sul State, Brazil, that were not included in the temporal comparative analysis.

Syrigma sibilatrix; Bubulcus ibis; Egretta thula; Phimosus infuscatus; Coragyps atratus; Cathartes aura; Buteo brachyurus; Caracara plancus; Milvago chimachima; Milvago chimango; Falco sparverius; Lurocalis semitorquatus; Hydropsalis torquata; Jacana jacana; Vanellus chilensis; Columba livia; Zenaida auriculata; Columbina talpacoti; Columbina picui; Myiopsitta monachus; Guira guira; Crotophaga ani; Tyto alba; Athene cunicularia; Chaetura meridionalis; Colaptes campestris; Furnarius rufus; Xolmis irupero; Satrapa icterophrys; Machetornis rixosa; Pitangus sulphuratus; Tyrannus savana; Tyrannus melancholicus; Progne tapera; Pygochelidon cyanoleuca; Mimus saturninus; Zonotrichia capensis; Sicalis flaveola; Volatinia jacarina; Sporophila caerulescens; Molothrus bonariensis; Estrilda astrild; Passer domesticus. 